\title{
SHIFTING FROM PRESUMPTIVE TO TEST-BASED MANAGEMENT OF MALARIA - TECHNICAL BASIS AND IMPLICATIONS FOR MALARIA CONTROL IN GHANA
}

\author{
F. BAIDEN ${ }^{1}$, K. MALM ${ }^{2}$, C. BART-PLANGE ${ }^{2}$, A. HODGSON $^{3}$, D. CHANDRAMOHAN ${ }^{4}$, \\ J. WEBSTER ${ }^{4}$ and S. OWUSU-AGYEI
}

\author{
${ }^{1}$ Kintampo Health Research Centre, Ghana Health Service, Ghana ${ }^{2}$ National Malaria Control Program, \\ Ghana Health Service, Ghana ${ }^{3}$ Health Research and Development Division, Ghana Health Service, Ghana \\ ${ }^{4}$ Department of Disease Control, London School of Hygiene and Tropical Medicine, London, U.K
}

DOI: http://dx.doi.org/10.4314/gmj.v48i2.10

Author for correspondence: Dr Frank Baiden

Email: baidenf@gmail.com

Conflict of interest: None declared

\section{SUMMARY}

The presumptive approach was the World Health Organisation (WHO) recommended to the management of malaria for many years and this was incorporated into syndromic guidelines such as the Integrated Management of Childhood Illnesses (IMCI). In early 2010 however, WHO issued revised treatment guidelines that call for a shift from the presumptive to the testbased approach. Practically, this implies that in all suspected cases, the diagnosis of uncomplicated malaria should be confirmed using rapid test before treatment is initiated. This revision effectively brings to an end an era of clinical practice that span several years. Its implementation has important implications for the health systems in malaria-endemic countries. On the basis of research in Ghana and other countries, and evidence from program work, the Ghana National Malaria Control Program has issued revised national treatment guidelines that call for implementation of test-based management of malaria in all cases, and across all age groups. This article reviews the evidence and the technical basis for the shift to test-based management and examines the implications for malaria control in Ghana.

Keywords: malaria, presumptive diagnosis, test-based diagnosis, fever, Ghana

\section{INTRODUCTION}

Malaria causes an estimated 660000 deaths annually and remains a major cause of morbidity and mortality in high-endemic countries. ${ }^{1}$ Traditionally, two approaches have been adopted in the management of malaria: presumptive and test-based.
The presumptive approach relies solely on clinical symptoms and signs to establish diagnosis and initiate treatment. In contrast, the test-based approach requires confirmation, either parasitological or antigen-antibody test, before the diagnosis of malaria can be made, and treatment initiated.

For many years, the World Health Organisation (WHO) recommended the presumptive approach and this was implemented across countries in malariaendemic, sub-Saharan Africa. In early 2010 however, WHO issued revised treatment guidelines that call for a shift from presumptive to test-based approach. This revision to the guidelines effectively brings to an end the practices of several decades. ${ }^{2-4}$ This article reviews the evidence-base for the shift to the test-based approach, and examines implications of its implementation in Ghana.

Justifications for the presumptive diagnosis of malaria

The major justifications for the presumptive approach to managing malaria in high-endemic countries were: (1) The high levels of transmission and associated morbidity and mortality; (2) The availability of affordable, yet effective antimalarials; (3) The lack of appropriate diagnostic tools. ${ }^{5-8}$

High transmission, and associated levels of morbidity and mortality

For many years, in high-transmission settings malaria was considered to be either the primary cause of all febrile illnesses or a major contributory factor. ${ }^{7,9-11}$ Studies from sub-Saharan Africa suggested that asymptomatic parasitaemia in children in high-transmission settings could be as high as $71 \%$ in under-five children $^{12}$, and between $37 \%$ and $68 \%$ in children aged 
up to ten years of age. ${ }^{13,14}$ A hospital-based study in Kenya in 1996 found that up to $45 \%$ of children admitted with respiratory signs (indicative of severe ARI) had malaria as the primary diagnosis. ${ }^{15}$ In Ghana and Kenya, the probability of fever that could be attributed to malaria was found to be as high as $61 \%$ and $67 \%$ respectively. ${ }^{16,17}$

Up to half of all mortality among African children aged 6 months to 5 years was considered to be due to malaria ${ }^{18}$ and nearly $3 \%$ of disability adjusted life years was attributed to malaria mortality globally. ${ }^{19}$

With such high levels of malaria-related morbidity and mortality, it was considered neither cost-effective nor safe to routinely distinguish malaria from non-malaria cases, and restrict antimalarial drugs to only confirmed cases, particularly where the attempt to do so could lead to rapid clinical deterioration and possibly death. The evidence supported the use of fever as a proxy indicator of malaria in both clinical care and epidemiological surveys. ${ }^{7,20,21}$

Availability of affordable, yet effective antimalarials The availability of affordable, yet effective antimalarials such as chloroquine (CQ) and sulphadoxinepyrimethamine (SP) was another important justification for the presumptive approach. Both were effective first-line antimalarial drugs in endemic countries in sub-Saharan Africa for many years. Being synthetic products, CQ and SP were cheap to produce and were affordable. They were also safe to use, including as chemoprophylaxis in pregnant women. Drug pressure exerted through their use in the presumptive treatment of uncomplicated malaria ${ }^{22}$ contributed to development of resistance.

In 2004, Ghana joined many countries across subSaharan Africa in changing its first-line drug for the treatment of uncomplicated malaria from chloroquine to artemisinin-based combination treatments. Reports of resistance and or prolonged parasite clearance associated with use of the artemisinins in Western Cambodia, and along the Thailand-Myanmar (Burma) border raise concern about the need to protect the ACTs from unwarranted use. ${ }^{23-25}$

\section{Lack of appropriate diagnostic tools}

The lack of easy-to-use, accurate and reliable malaria diagnostic tools was another important justification for adoption of the presumptive approach. 7, 26, 27 Blood smear microscopy using Giemsa stain techniques which had been the mainstay of parasitological confirmation of malaria for many years, was too elaborate, technical, and expensive to set-up and maintain in all primary care facilities and was time-consuming. Elec- tricity or an alternate source of power, and clean water is needed, neither of which are reliably available in most parts of sub-Saharan Africa where primary care facilities are situated. ${ }^{28-30}$ The availability of skilled microscopists to prepare and read slides accurately and reliably is an added challenge in low and middleincome countries. ${ }^{31,32}$

A diagnostic tool that could be easily and rapidly applied to many patients within a short time was needed. Such a diagnostic test needed to be one that both professional and non-professional health workers could perform.

Presumptive management of malaria formed the basis of the treatment of malaria within the Integrated Management of Childhood Illnesses (IMCI) where all under-five children who presented with fever were prescribed an antimalarial.

\section{Arguments for and against the shift}

It is now argued that the presumptive approach is no longer justifiable and there is a need to shift to the testbased approach. ${ }^{33-35}$ However, the decision to shift from presumptive to test-based approach in managing malaria has occasioned considerable debate. 6, 36-38 Those who favoured the shift to test-based management of malaria argued that the factors that justified the presumptive approach were no longer valid. Malaria transmission, originally high, has been declining and affordable antimalarials were no longer effective and had been replaced with the more expensive artemisinin-based combination therapy (ACT). They also argued that smear microscopy was no longer the only practical means of confirming the diagnosis of malaria at the point of care due to the availability of malaria rapid diagnostic tests (mRDTs). Those who favoured the shift further argued that test-based approach would lead to improvement in the management of non-malaria febrile illnesses. ${ }^{33}$

Those who opposed the shift to test based management argued that there was insufficient evidence that malaria was on a sustainable decline. They questioned the capacity of malaria-endemic country health systems to sustain stock of quality-assured RDTs. They further believed that there was insufficient evidence on the safety of restricting ACT to test-positive cases and that a policy of test-based management of malaria would not necessarily lead to improvement in the management of non-malarial febrile illnesses. ${ }^{38,39}$

In evaluating the appropriateness of implementing the shift to test-based management of malaria in Ghana, it is important to assess whether local and sub-regional 
evidence, supports the decline of malaria and whether the available RDTs are accurate and reliable.

\section{Is malaria on a sustainable decline?}

Recent reports suggest that the burden of malaria is declining in many areas of sub-Saharan Africa. ${ }^{40,41}$ According to the 2010 and 2011 World Malaria Reports, appreciable progress was made between 2000 and 2010 to reduce the burden of malaria globally. A $26 \%$ decline in malaria deaths was recorded globally, with sub-Saharan Africa accounting for $33 \%$ of this decline.

In the same period, the number of malaria cases per 1000 persons at risk declined by about $17 \%{ }^{42,}{ }^{43} \mathrm{Be}-$ tween 1985-1999 and 2000-2007, Plasmodium falciparum prevalence rates among children aged 2 to 10 years in sub-Saharan Africa declined from $37 \%$ in $1985-1999$ to $17 \%$ in $2000-2007 .^{14,33}$

\section{MALARIA PARASITE PREVALENCE IN GHANA, 2012}

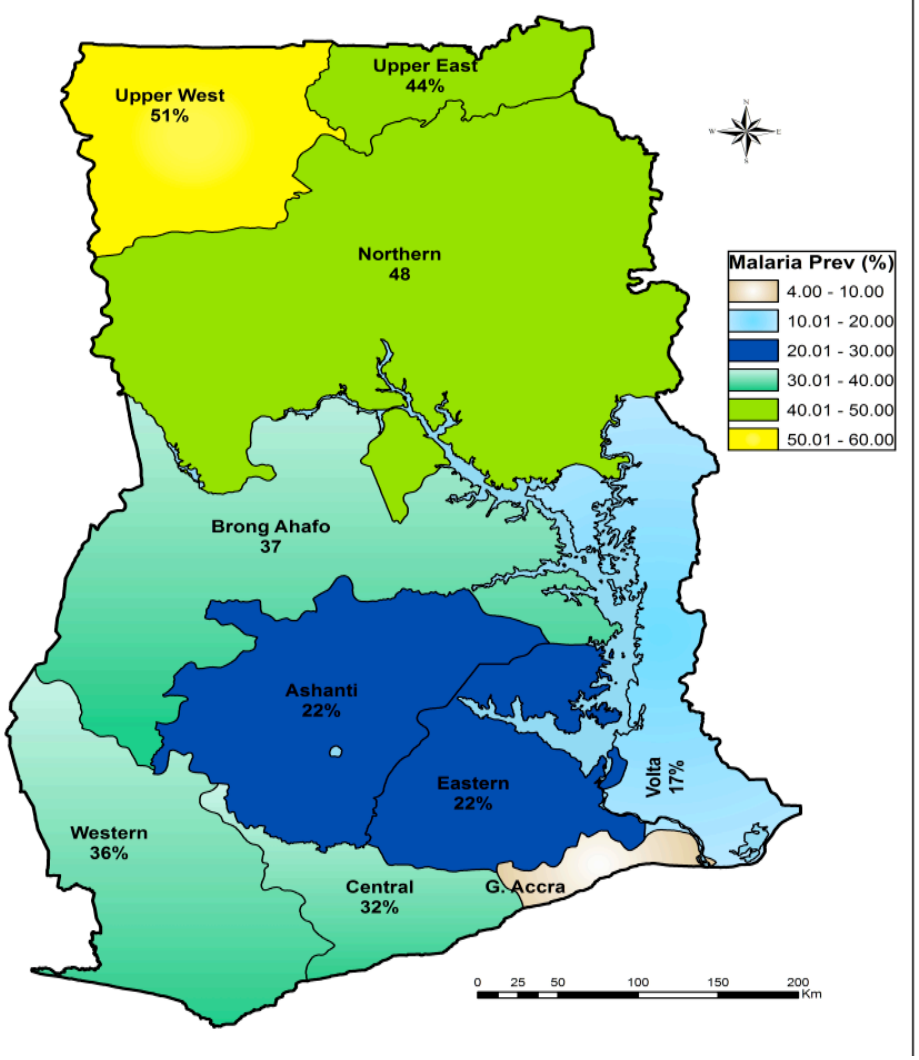

Figure 1 Prevalence of malaria parasitaemia among under-five children in the ten regions of Ghana (Source: MICS 2011 ${ }^{47}$ )

In Zanzibar, data from routine health services and clinico-parasitological surveys have been used to demonstrate that between 2002 and 2006, malaria- related admissions, blood transfusions, and malariaattributed mortality declined by $77 \%, 67 \%$ and $75 \%$ respectively. A further 10 -fold reduction in malaria parasite prevalence was achieved in that country in 2006 after the introduction of long-lasting insecticidal nets. ${ }^{44}$ In The Gambia, findings from a retrospective analysis of records on numbers and proportions of malaria in-patients, deaths, blood-slide examinations at five health facilities over periods ranging from 7 years to 9 years has suggested that a "large proportion of the burden of malaria in that country has been alleviated." ${ }^{45}$ In Uganda, a study in four districts in 2007 found dramatically lower-than-expected levels of parasitaemia among children with fever presenting to health facilities. Parasitaemia ranged from $13.9 \%$ in patients $\geq 5$ years in medium-to-high transmission areas to $50.5 \%$ for children $<5$ years in very high transmission areas. These districts had historically been known to record some of the highest entomological inoculation rates (between 564 and 1,564 infective bytes per person per year) in the world. ${ }^{46}$ Table 1 provides examples of recent reports of reduction in the burden of malaria in sub-Saharan Africa and the factors reported to be underlying the reductions.

Ghana is classified as being high malaria-transmission. Evidence is however emerging about substantial reduction in malaria transmission in the country. The findings of the recent Multiple Indicator Cluster Survey (MICS) confirm dramatically low levels of malaria parasitaemia among under-five children across the country. The proportions of under-five children found to have parasitaemia ranged from as low as $4 \%$ in Accra to $51 \%$ in the Upper-West region (Figure 1). ${ }^{47}$ These findings contrast with much higher prevalence recorded in similar surveys in the past. ${ }^{12,48}$

The National Malaria Programme (NMCP) is in the process of establishing sentinel sites across the country where all febrile cases presenting to sentinel facilities will be tested and malaria parasitaemia recorded will be used as a proxy indicator of levels of malaria transmission. Research into the development of alternative simple tools for monitoring the burden of malaria in Ghana is also underway.

\section{Are accurate and reliable RDTs available?}

Although mRDTs were developed in the early 1990s, their use in routine health services was limited by the lack of international standards for comparing the different brands. Malaria programs had no evidence base to guide procurement decisions. The WHO/FIND/CDC-supported program for testing commercially available RDT products and ranking them according to performance now provides this evidence. 
Table 1 Examples of studies that report reduction in the burden of malaria in sub-Saharan Africa.

\begin{tabular}{|c|c|c|c|c|c|c|c|c|c|c|c|}
\hline \multirow[b]{2}{*}{ Country } & \multirow[b]{2}{*}{$\begin{array}{l}\text { Study } \\
\text { Design }\end{array}$} & \multirow[b]{2}{*}{$\begin{array}{l}\text { Character of } \\
\text { site }\end{array}$} & \multirow[b]{2}{*}{ Reported reduction } & \multirow[b]{2}{*}{$\begin{array}{l}\text { Observed } \\
\text { period of } \\
\text { decline }\end{array}$} & \multicolumn{2}{|c|}{$\begin{array}{l}\text { Control or compar- } \\
\text { ator }\end{array}$} & \multirow[b]{2}{*}{$\begin{array}{l}\text { Adjust } \\
\text { just- } \\
\text { ment } \\
\text { for } \\
\text { Rain- } \\
\text { fall }\end{array}$} & \multicolumn{3}{|c|}{$\begin{array}{l}\text { Time of deployment relative to evidence of malaria } \\
\text { decline }\end{array}$} & \multirow[b]{2}{*}{ Reported Reasons } \\
\hline & & & & & $\begin{array}{l}\text { Non- } \\
\text { malarial } \\
\text { cases }\end{array}$ & $\begin{array}{l}\text { Non- } \\
\text { inter- } \\
\text { ven- } \\
\text { tion } \\
\text { area } \\
\text { or } \\
\text { prior } \\
\text { data } \\
\end{array}$ & & ACT & ITN & IRS & \\
\hline $\begin{array}{l}\text { Coastal } \\
\text { Kenya }^{77}\end{array}$ & $\begin{array}{l}\text { Retrospective review of } \\
\text { routine HMIS data }\end{array}$ & $\begin{array}{l}\text { One routinely } \\
\text { researched site } \\
\text { and two ad- } \\
\text { joining non- } \\
\text { research sites }\end{array}$ & $\begin{array}{l}63 \%, 53 \% \text { and } 28 \% \text { reduction } \\
\text { in malaria cases in } 3 \text { district } \\
\text { hospitals }\end{array}$ & $\begin{array}{l}1999, \\
2006\end{array}$ & Yes & Yes & Yes & After & After & Not deployed & $\begin{array}{l}\text { Malaria control interven- } \\
\text { tions }\end{array}$ \\
\hline $\begin{array}{l}\text { Ifakara, } \\
\text { Tanzania }^{78}\end{array}$ & $\begin{array}{l}\text { Retrospective review of data } \\
\text { from cohort studies }\end{array}$ & $\begin{array}{l}\text { Routinely } \\
\text { researched site }\end{array}$ & $\begin{array}{l}\text { Reduced from } 0.8 \text { to } 0.43 \\
\text { episodes per child per year }\end{array}$ & $1995-2000$ & Yes & No & No & After & $\begin{array}{l}\text { After. Net used } \\
\text { before were mostly } \\
\text { untreated and at } \\
\text { coverage less than } \\
20 \%\end{array}$ & Not deployed & $\begin{array}{l}\text { Economic improvements, } \\
\text { liberalization of health } \\
\text { sector and malaria control } \\
\text { interventions }\end{array}$ \\
\hline $\begin{array}{l}\text { Zanzibar, Tan- } \\
\text { zania }^{44}\end{array}$ & $\begin{array}{l}\text { Before and After interven- } \\
\text { tion }\end{array}$ & $\begin{array}{l}\text { Not routinely } \\
\text { researched }\end{array}$ & $\begin{array}{l}77 \% \text { reduction in malaria } \\
\text { admissions }\end{array}$ & $\begin{array}{l}2003- \\
2005\end{array}$ & No & Yes & Yes & Before & Before & After & $\begin{array}{ll}\text { Artemisinin combination } \\
\text { Therapy and Insecticide } \\
\text { Treated Nets }\end{array}$ \\
\hline $\begin{array}{l}\text { Mozambique, } \\
\text { South Africa } \\
\text { and Swaziland }{ }^{79}\end{array}$ & $\begin{array}{l}\text { Before and After interven- } \\
\text { tion }\end{array}$ & $\begin{array}{l}\text { Not routinely } \\
\text { researched }\end{array}$ & $\begin{array}{l}>60 \% \text { fall in parasite preva- } \\
\text { lence in all } 3 \text { zones studied }\end{array}$ & $\begin{array}{l}1999- \\
2005\end{array}$ & No & Yes & No & After & Not deployed & Before & Indoor residual spraying \\
\hline Guinea-Bissau ${ }^{80}$ & $\begin{array}{l}\text { Comparative, } \quad \text { Cross- } \\
\text { sectional }\end{array}$ & $\begin{array}{l}\text { Routinely } \\
\text { researched site }\end{array}$ & Reduced from $44-79 \%$ to $3 \%$ & $\begin{array}{l}1994, \\
1999 \\
2003-4 \\
\end{array}$ & No & Yes & No** & After & $\begin{array}{l}\text { After. Only } 5 \% \text { of } \\
\text { nets used before } \\
\text { were treated }\end{array}$ & Not deployed & $\begin{array}{l}\text { Untreated bed nets and } \\
\text { urbanization }\end{array}$ \\
\hline Eritrea $^{81}$ & $\begin{array}{l}\text { Before (Retrospective re- } \\
\text { view of routine HMIS data) } \\
\text { and After (cross-sectional } \\
\text { survey) intervention }\end{array}$ & $\begin{array}{l}\text { Not routinely } \\
\text { researched }\end{array}$ & $\begin{array}{l}\text { Decrease in malaria incidence } \\
\text { of } 83.3 \% \text { and case fatality by } \\
\text { from } 0.21 \text { to } 0.14 \%\end{array}$ & $2000-4$ & No & Yes & No*** & $\begin{array}{l}\text { Not } \\
\text { de- } \\
\text { ployed }\end{array}$ & Before & Before & $\begin{array}{l}\text { Climate change and malaria } \\
\text { control methods (ITNs, IRS } \\
\text { and early case detection and } \\
\text { treatment) }\end{array}$ \\
\hline $\begin{array}{l}\text { Rwanda and } \\
\text { Ethiopia }^{82}\end{array}$ & $\begin{array}{l}\text { Before and After interven- } \\
\text { tion }\end{array}$ & $\begin{array}{l}\text { Not routinely } \\
\text { researched }\end{array}$ & $\begin{array}{l}55 \% \text { and } 73 \% \text { fall in under-5 } \\
\text { in-patient cases in Rwanda \& } \\
\text { Ethiopia }\end{array}$ & $2001-7$ & Yes & Yes & No & Before & Before & $\begin{array}{l}\text { Not deployed. } \\
\text { Used routinely } \\
\text { before and after } \\
\text { in Ethiopia }\end{array}$ & $\begin{array}{l}\text { Stronger correlation with } \\
\text { ACT and ITN scale-up in } \\
\text { Rwanda. Less firmer in the } \\
\text { case of Ethiopia due to } \\
\text { epidemic nature of trans- } \\
\text { mission }\end{array}$ \\
\hline Senegal ${ }^{83}$ & $\begin{array}{l}\text { Prospective. Nested in clini- } \\
\text { cal trial }\end{array}$ & $\begin{array}{l}\text { Not routinely } \\
\text { researched. }\end{array}$ & $\begin{array}{l}\text { Incidence rate from } 46.1 \% \text { to } \\
37.5 \%\end{array}$ & $\begin{array}{l}1998 \\
2002 \\
\end{array}$ & No & No & No*** & Before & Not deployed & Not deployed & $\begin{array}{l}\text { None particularly } \\
\text { ACT considered unlikely }\end{array}$ \\
\hline Tanzania ${ }^{84}$ & $\begin{array}{l}\text { Before and After interven- } \\
\text { tion }\end{array}$ & $\begin{array}{l}\text { Not routinely } \\
\text { researched }\end{array}$ & 4-6-fold reduction in EIR, & $\begin{array}{l}1990-4 \text { to } \\
2001-3\end{array}$ & No & Yes & No & $\begin{array}{l}\text { Not } \\
\text { de- } \\
\text { ployed }\end{array}$ & Before & Not deployed & $\begin{array}{l}\text { Deployment of both treated } \\
\text { and untreated nets) }\end{array}$ \\
\hline South Africa ${ }^{85}$ & $\begin{array}{l}\text { Retrospective review of } \\
\text { routine HMIS data }\end{array}$ & $\begin{array}{l}\text { Not routinely } \\
\text { researched }\end{array}$ & $\begin{array}{l}99 \% \text { decline in cases and } \\
\text { admissions, } 97 \% \text { decline in } \\
\text { cases }\end{array}$ & $2000-3$ & No & Yes & No & Before & Not deployed & Before & $\begin{array}{l}\text { Attributable to mass de- } \\
\text { ployment of ACT and IRS }\end{array}$ \\
\hline Rwanda $^{86}$ & $\begin{array}{l}\text { Retrospective review of } \\
\text { routine HMIS data + House- } \\
\text { hold surveys }\end{array}$ & $\begin{array}{l}\text { Not routinely } \\
\text { researched }\end{array}$ & $\begin{array}{l}72 \% \text { decline in confirmed } \\
\text { cases, } 47 \% \text { decline in malaria } \\
\text { deaths }\end{array}$ & $2006-2010$ & Yes & Yes & No & Before & Before & Not deployed & $\begin{array}{l}\text { Scale-up in ITN and ACT } \\
\text { coverage }\end{array}$ \\
\hline
\end{tabular}


Table 2 Findings for Pubmed-indexed publications of RDT products evaluated in Ghana

\begin{tabular}{|c|c|c|c|c|}
\hline Product & Comparator & Main findings & Authors' conclusions & Reference \\
\hline Partec $\mathbb{R}$ & PCR & $\begin{array}{l}\text { Sensitivity }-62.2 \% \\
\text { Specificity }-96.0 \%\end{array}$ & Partec $\AA$ can be an alternative to microscopy. & Nkrumah et al $2010^{87}$ \\
\hline Partec $\mathbb{R}$ & \multirow{2}{*}{ Microscopy } & $\begin{array}{l}\text { Sensitivity - } 100 \% \\
\text { Specificity }-97.4 \%\end{array}$ & \multirow{2}{*}{ Both RDTs can be an alternative to microscopy } & \multirow{2}{*}{ Nkrumah et al $2011^{88}$} \\
\hline Binax Now ${ }^{\circledR}$ & & $\begin{array}{l}\text { Sensitivity }-97.2 \% \\
\text { Specificity }-93.6 \%\end{array}$ & & \\
\hline $\begin{array}{l}\text { DiaMed } \\
\text { OptiMal-IT® }\end{array}$ & Microscopy & $\begin{array}{l}\text { Sensitivity (Pregnant women) - 50.5\% } \\
\text { Sensitivity (Under-5 children) - 87.7\% } \\
\text { Specificity (Pregnant women) }-82.5 \% \\
\text { Specificity (Under-5 children) - 89.6\% }\end{array}$ & $\begin{array}{l}\text { DiaMed OptiMal-IT® tests should not replace } \\
\text { microscopy in our endemic setting }\end{array}$ & Ayeh-Kumi et al $2011^{89}$ \\
\hline CareStart $\AA$ & Microscopy & $\begin{array}{l}\text { Sensitivity }-100.0 \% \\
\text { Specificity }-73.0 \%\end{array}$ & CareStart $\AA$ can be an alternative to microscopy & Baiden et al $2012^{90}$ \\
\hline
\end{tabular}


The 'FIND reports' have become a reference point for the performance of different mRDTs. It has led to improvements in the quality and comparability of published mRDT evaluation studies. ${ }^{29}$

A Cochrane Database review of mRDT evaluation studies conducted in early 2010 identified 74 studies. Average sensitivities and specificities were found to be $94.8 \%(93.1 \%$ to $96.1 \%)$ and $95.2 \%(93.2 \%$ to $96.7 \%)$ respectively. The review concluded that the sensitivity and specificity of most mRDTs were such that they could be used to extend access to diagnostic confirmation in the management of uncomplicated $P$. falciparum malaria in sub-Saharan Africa. ${ }^{49}$ The findings from this review corroborated those from earlier reviews. ${ }^{50,51}$ and bolstered confidence that currentlyavailable RDTs could be as accurate as smear microscopy. There is currently very little dispute about the fact that there are many mRDTs that meet acceptable performance standards at high levels of parasitemia. ${ }^{49}$

There are of however concerns about hrp gene deletions in a certain proportion of the population and lower multiplicity of infections as malaria control improves. Both of which could result in false negative tests. The next generation of RDTs which are currently in development will aim to target different antigens. ${ }^{52}$

A PubMed search with combinations of the terms "rapid test", "malaria" and "Ghana" conducted in February 2013 yielded four studies that evaluated the performance of different brands of mRDTs under controlled conditions. The summary of evidence supports the position that there are currently available mRDTs whose performance meets internationally acceptable standards and which can be relied upon to make clinical decision. However the poor sensitivity of DiaMed OptiMal-IT $\AA$ in pregnant women $(50.5 \%)$ compared to $(87.5 \%)$ in children under 5 years gives cause for caution that the performances of mRDTs could vary according to the population in which it is used. (Table 2)

\section{Implications for malaria control in Ghana} Ensuring supply of quality-assured mRDTs

While accurate mRDTs can be procured and used in clinical care, there remain concerns about the frequency of false-positive results produced by mRDTs that detect histidine-rich protein-2 antigen (HRP2-based mRDTs). This antigen is produced by the malaria parasite but persists in the blood long after the parasite has been destroyed. The persistence of HRP-2 in the blood gives rise to false-positive $\mathrm{mRDT}$ results which, in the absence of careful clinical assessment, could distort the clinical picture and lead to a diagnosis of malaria at the expense of identifying the underlying cause of the illness.
Another challenge is the possibility of false-negative results due to low levels of parasitaemia. A falsenegative $\mathrm{mRDT}$ result could cause delay in the initiation of treatment. In children, this could lead to severe malaria, with possible disability or death. ${ }^{39}$ In a move to address this problem, WHO has recently adjusted the panel detection score in its program of RDT evaluation from $50 \%$ to $75 \%$ for $P$. falciparum in areas of high transmission. ${ }^{53}$ This move further raises the standards required of commercially-produced RDTs.

At present there is no local production of mRDTs in Ghana. As such all the RDTs that are used in the country are imported. Those that the Ministry of Health in Ghana imports are pre-qualified by the WHO and guaranteed to be of good quality. However the liberal trading regime in Ghana means that mRDTs enter the country through other sources and may not be monitored. It is important for regulatory authorities to be alert to the high possibility that sub-standard mRDTs could be imported into the country and into clinical use. ${ }^{54}$ Currently, there are proposals at WHO for the development of kits that clinicians can use to check the quality of mRDTs at point-of-care. ${ }^{55,56}$ Until these become available however, clinicians and health facilities will still need to be careful about the brands of mRDTs that they procure for use in clinical care.

\section{Ensuring health workers adhere to mRDT results and restrict to only positive cases}

A major factor affecting effective implementation of health interventions in sub-Saharan Africa is the attitude of health workers. Inadequate health-worker performance is a very widespread problem and experience has shown that adherence to clinical guidelines is often low. ${ }^{57}$ The cost-effectiveness of implementing testbased management of malaria hinges on health workers adhering to test-results and restricting ACTs to testpositive cases while looking for other causes of fever in the test-negative cases.

The concern that health workers may not adhere to testresults is largely founded on the use of smear microscopy in clinical care in the past. Many clinicians and other health workers in malaria-endemic countries treat patients with antimalarials even after receiving negative parasitological test results. ${ }^{58}$ The rate at which clinicians across sub-Saharan Africa have ignored negative test results and prescribed antimalarial have ranged from $50 \%$ to $90 \%$. $^{59,6058}$

Emerging evidence suggests, however, that once clinicians gain confidence with the use of test-based management and find a correlation between the results of the test and clinical outcome, adherence to test-results improves. 
In Senegal test-based management of malaria using RDT was incorporated into national policy in September 2007. In the first year following implementation, the RDT-positive rate lagged well behind ACT consumption and this was attributed to health worker nonadherence to test results. By mid-2008 however, the RDT-positive rate and ACT consumption had nearly equalled. This corresponding use in mRDT and ACT was sustained through the rest of 2008, and throughout 2009. ${ }^{61}$

A similar observation has been made in a study in Kenya where text-message reminders were used to improve ACT malaria case management practices. Immediately after the introduction of the intervention, a $23.7 \%$ improvement in adherence was reported. This increased to $24.5 \% 6$ months later. ${ }^{62}$ These observations suggest that health worker non-adherence to mRDT results may be short-lived and improve over time.

\section{Ensuring effective management of non-malaria fe- vers}

Closely related to health worker adherence to test results is ensuring that health workers are able to effectively manage the alternative diagnosis. The introduction of test-based management of malaria will lead to a significant increase in the number of non-malarial febrile illnesses. A challenge that this poses is how clinicians can appropriately manage this group of illnesses. ${ }^{4,63}$

The many years of over-diagnosis and over-emphasis on malaria have been at the expense of attention to non-malaria febrile illnesses. As a result, the capacity for their diagnosis and management remain poorly developed. While the introduction of mRDT will improve the diagnosis of malaria, and more clearly delineate the burden of non-malarial febrile illnesses, it will not lead to improvement in the knowledge of the aetiology of non-malarial febrile illnesses. In the absence of appropriate diagnostic tools therefore, health workers are likely to either overlook negative malaria test results and still prescribe antimalarials (non-adherence) or presumptively administer antibiotics to all cases of non-malarial febrile illnesses. Essentially, clinicians will be substituting the blinded use of ACTs (in the presumptive approach) with the blinded use of antibiotics. $^{63}$

Self-terminating viral infections are a common cause of fevers in malaria-endemic countries, particularly under-five children. Their management does not require the use of antibiotics. However it will be extremely challenging to ask a primary care health worker in a rural area to deny patients both antimalarials and anti- biotics, particularly when the condition has not been confirmed to be of non-bacterial origin. ${ }^{64}$ In Cameroun, the difficulty health workers encountered with the management of non-malarial illnesses was evident in delayed appropriate treatment for children with these conditions. ${ }^{65}$

Evidence is emerging on the potential for test-based management of malaria to lead to increased inappropriate use of antibiotics in malaria-endemic countries in sub-Saharan Africa. In Zanzibar the introduction of RDT led to an increase in the prescription of antibiotics from $27 \%$ to $37 \%$. ${ }^{66}$ This phenomenon has been similarly reported of studies in other parts of sub-Saharan Africa.

These increases in antibiotic use are considered to be due to the presumptive use of antibiotics to treat nonmalarial febrile illnesses. ${ }^{67-69}$ Improvement in the management of non-malarial febrile illnesses should be considered integral to the process of shifting from presumptive to test-based management of malaria. An important implication of the implementation of testbased management of malaria is the need to ensure that it does not lead to irrational use of antibiotics.

If the shift to test-based management of malaria is to lead to improvement in the management of nonmalarial febrile illnesses in under-five children, then mRDTs must be introduced into the health system as an integral part of the management of tropical fevers, and not just the management of malaria alone. ${ }^{64,70}$ This is particularly important in the case under-five children, since the recommended approach to the management of fevers in this age group is clearly-defined within the Integrated Management of Childhood Illnesses (IMCI) which has for many years promoted the presumptive approach to malaria treatment. $7,71,72$

In Ghana, the Family Health Division of the health service develops the overarching guidelines for the management of under-five febrile illnesses. Although within the Ghana Health Service (GHS), this division is separate from the National Malaria Control Program (NMCP). Revisions to the malaria treatment guidelines alone do not guarantee application in under-five children unless it is matched by corresponding revision in the IMCI guidelines.

\section{Nurturing and sustaining patient acceptability}

The implementation of test-based management of malaria places additional responsibility on clinicians regarding the education of patients, particularly the parents or guardians (caregivers) of under-five children living in areas where presumptive treatment was practiced for many years. ${ }^{73-75}$ There are three important 
aspects of the revised approach that caregivers may possibly react to. These are the failure to prescribe ACTs in all cases of childhood fevers, the drawing of blood to perform the tests in primary care settings, and the increased cost of care in some places due to introduction of RDTs.

In Ghana, the likely attitude of health workers towards the shift to test-based management of malaria has been assessed in a survey among 3047 caregivers of under 5 children in the Brong Ahafo region. Nearly all (98\%) caregiver reported a preference for the test-based approach. The major factor that promoted acceptability included the perception that a blood test at the health centre level represented improvement in the quality of care, and was likely to lead to improved treatment outcomes. $^{76}$

The success or otherwise of the implementation of testbased management of malaria in Ghana will depend on how it leads to improved treatment outcomes for both malaria and non-malarial febrile illnesses, and how it impacts on the epidemiology of malaria in the country. There is thus now a need for improved malaria surveillance, improved diagnosis and management of nonmalarial febrile illnesses and continued collaboration between clinicians, epidemiologists and program managers.

\section{REFERENCES}

1. WHO. World Malaria Report. Geneva, Switzerland: World Health Organization; 2012.

2. Guinovart C, Bassat Q, Sigauque B, Aide P, Sacarlal J, Nhampossa $T$, et al. Malaria in rural Mozambique. Part I: children attending the outpatient clinic. Malar J. 2008; 7: 36.

3. Tarimo DS, Minjas JN, Bygbjerg IC. Malaria diagnosis and treatment under the strategy of the integrated management of childhood illness (IMCI): relevance of laboratory support from the rapid immunochromatographic tests of ICT Malaria P.f/P.v and OptiMal. Ann Trop Med Parasitol. 2001; 95(5): 437-44.

4. World Health Organisation. Parasitological confirmation of malaria diagnosis: WHO technical consultation, Geneva, 6-8 October 2009. Geneva: World Health Organisation; 2009.

5. Chandramohan D, Jaffar S, Greenwood B. Use of clinical algorithms for diagnosing malaria. Trop Med Int Health. 2002; 7(1): 45-52.

6. Gosling RD, Drakeley CJ, Mwita A, Chandramohan D. Presumptive treatment of fever cases as malaria: help or hindrance for malaria control? Malar J. 2008; 7: 132.

7. Gove S. Integrated management of childhood illness by outpatient health workers: technical basis and overview. The WHO Working Group on Guidelines for Integrated Management of the Sick Child. Bull World Health Organ. 1997; 75 Suppl 1: 7-24.

8. Nsimba SE, Massele AY, Eriksen J, Gustafsson LL, Tomson G, Warsame M. Case management of malaria in under-fives at primary health care facilities in a Tanzanian district. Trop Med Int Health. 2002; 7(3): 201-9.

9. Bouvier P, Rougemont A, Breslow N, Doumbo O, Delley V, Dicko A, et al. Seasonality and malaria in a west African village: does high parasite density predict fever incidence? Am J Epidemiol. 1997; 145(9): 850-7. 10. Hogh B. Clinical and parasitological studies on immunity to Plasmodium falciparum malaria in children. Scand J Infect Dis Suppl. 1996; 102: 1-53.

11. Rougemont A, Breslow N, Brenner E, Moret AL, Dumbo O, Dolo A, et al. Epidemiological basis for clinical diagnosis of childhood malaria in endemic zone in West Africa. Lancet. 1991; 338(8778): 1292-5. 12. Koram KA, Owusu-Agyei S, Utz G, Binka FN, Baird JK, Hoffman SL, et al. Severe anemia in young children after high and low malaria transmission seasons in the Kassena-Nankana district of northern Ghana. Am J Trop Med Hyg. 2000; 62(6): 670-4.

13. Agyepong IA, Kangeya-Kayonda J. Providing practical estimates of malaria burden for health planners in resource-poor countries. Am J Trop Med Hyg. 2004; 71(2 Suppl): 162-7.

14. Guerra CA, Gikandi PW, Tatem AJ, Noor AM, Smith DL, Hay SI, et al. The limits and intensity of Plasmodium falciparum transmission: implications for malaria control and elimination worldwide. PLoS Med. 2008; 5(2): e38.

15. English M, Punt J, Mwangi I, McHugh K, Marsh K. Clinical overlap between malaria and severe pneumonia in Africa children in hospital. Trans $R$ Soc Trop Med Hyg. 1996; 90(6): 658-62.

16. Perkins BA, Zucker JR, Otieno J, Jafari HS, Paxton L, Redd SC, et al. Evaluation of an algorithm for integrated management of childhood illness in an area of Kenya with high malaria transmission. Bull World Health Organ. 1997; 75 Suppl 1: 33-42.

17. Rogers WO, Atuguba F, Oduro AR, Hodgson A, Koram KA. Clinical case definitions and malaria vaccine efficacy. J Infect Dis. 2006; 193(3): 467-73.

18. Pasvol G. The treatment of falciparum malaria in African children. Afr Health. 1998; 20(4): 19-20.

19. Breman JG, Alilio MS, Mills A. Conquering the intolerable burden of malaria: what's new, what's needed: a summary. Am J Trop Med Hyg. 2004; 71(2 Suppl): 1-15.

20. Korenromp EL, Miller J, Cibulskis RE, Cham MK, Alnwick D, Dye C. Monitoring mosquito net coverage for malaria control in Africa: possession vs. use by children under 5 years. Trop Med Int Health. 2003; 8(8): 693-703. 
21. Nonvignon J, Aikins MKS, Chinbuah MA, Abbey M, Gyapong M, Garshong BNA, et al. Treatment choices for fevers in children under-five years in a rural Ghanaian district. Malar J. 2010; 9.

22. Whitty CJ, Chandler C, Ansah E, Leslie T, Staedke SG. Deployment of ACT antimalarials for treatment of malaria: challenges and opportunities. Malar J. 2008; 7 Suppl 1: S7.

23. Cheeseman IH, Miller BA, Nair S, Nkhoma S, Tan A, Tan JC, et al. A major genome region underlying artemisinin resistance in malaria. Science. 2012; 336(6077): 79-82.

24. Dondorp AM, Yeung S, White L, Nguon C, Day NP, Socheat D, et al. Artemisinin resistance: current status and scenarios for containment. Nat Rev Microbiol. 2010; 8(4): 272-80.

25. Phyo AP, Nkhoma S, Stepniewska K, Ashley EA, Nair S, McGready R, et al. Emergence of artemisininresistant malaria on the western border of Thailand: a longitudinal study. Lancet. 2012; 379(9830): 1960-6.

26. Gething PW, Kirui VC, Alegana VA, Okiro EA, Noor AM, Snow RW. Estimating the number of paediatric fevers associated with malaria infection presenting to Africa's public health sector in 2007. PLoS Med. 2010; 7(7): e1000301.

27. Pagnoni F, Convelbo N, Tiendrebeogo J, Cousens $\mathrm{S}$, Esposito F. A community-based programme to provide prompt and adequate treatment of presumptive malaria in children. Trans R Soc Trop Med Hyg. 1997; 91(5): 512-7.

28. Kahama-Maro J, D'Acremont V, Mtasiwa D, Genton B, Lengeler C. Low quality of routine microscopy for malaria at different levels of the health system in Dar es Salaam. Malar J. 2011; 10: 332.

29. Perkins MD, Bell DR. Working without a blindfold: the critical role of diagnostics in malaria control. Malar J. 2008; 7 Suppl 1: S5.

30. Wongsrichanalai C, Barcus MJ, Muth S, Sutamihardja A, Wernsdorfer WH. A review of malaria diagnostic tools: microscopy and rapid diagnostic test (RDT). Am J Trop Med Hyg. 2007; 77(6 Suppl): 11927.

31. Kruk ME, Prescott MR, de Pinho H, Galea S. Are doctors and nurses associated with coverage of essential health services in developing countries? A cross-sectional study. Hum Resour Health. 2009; 7: 27. 32. Clemens MA, Pettersson G. New data on African health professionals abroad. Hum Resour Health. 2008; 6: 1 .

33. D'Acremont V, Lengeler C, Mshinda H, Mtasiwa D, Tanner M, Genton B. Time to move from presumptive malaria treatment to laboratory-confirmed diagnosis and treatment in African children with fever. PLoS Med. 2009; 6(1): e252.
34. WHO. Guidelines for the treatment of malaria. 2nd ed. Geneva: World Health Organization 2nd Edition; 2010.

35. Ye Y, Madise N, Ndugwa R, Ochola S, Snow RW. Fever treatment in the absence of malaria transmission in an urban informal settlement in Nairobi, Kenya. Malar J. 2009; 8: 160.

36. Bisoffi Z, Gobbi F, Buonfrate D, Van den Ende J. Diagnosis of Malaria Infection with or without Disease. Mediterr J Hematol Infect Dis. 2012; 4(1): e2012036.

37. Bisoffi Z, Sirima SB, Meheus F, Lodesani C, Gobbi F, Angheben A, et al. Strict adherence to malaria rapid test results might lead to a neglect of other dangerous diseases: a cost benefit analysis from Burkina Faso. Malar J. 2011; 10: 226.

38. Graz B, Willcox M, Szeless T, Rougemont A. "Test and treat" or presumptive treatment for malaria in high transmission situations? A reflection on the latest WHO guidelines. Malar J. 2011; 10: 136.

39. English M, Reyburn H, Goodman C, Snow RW. Abandoning presumptive antimalarial treatment for febrile children aged less than five years--a case of running before we can walk? PLoS Med. 2009; 6(1): e1000015.

40. Mudhune SA, Okiro EA, Noor AM, Zurovac D, Juma E, Ochola SA, et al. The clinical burden of malaria in Nairobi: a historical review and contemporary audit. Malar J. 2011; 10: 138.

41. O'Meara WP, Mangeni JN, Steketee R, Greenwood B. Changes in the burden of malaria in sub-Saharan Africa. Lancet Infect Dis. 2010; 10(8): 545-55.

42. WHO. World malaria report. Geneva, Switzerland: World Health Organization.; 2010.

43. WHO. World malaria report. Geneva, Switzerland: World Health Organization; 2011.

44. Bhattarai A, Ali AS, Kachur SP, Martensson A, Abbas AK, Khatib R, et al. Impact of artemisinin-based combination therapy and insecticide-treated nets on malaria burden in Zanzibar. PLoS Med. 2007; 4(11): e309.

45. Ceesay SJ, Casals-Pascual C, Erskine J, Anya SE, Duah NO, Fulford AJ, et al. Changes in malaria indices between 1999 and 2007 in The Gambia: a retrospective analysis. Lancet. 2008; 372(9649): 1545-54.

46. Nankabirwa J, Zurovac D, Njogu JN, Rwakimari JB, Counihan H, Snow RW, et al. Malaria misdiagnosis in Uganda--implications for policy change. Malar J. 2009; 8: 66.

47. Ghana Statistical Service. Malaria Indicator Cluster Survey 2011. Accra: Ghana Statistical Service; 2012.

48. Owusu-Agyei S, Fryauff DJ, Chandramohan D, Koram KA, Binka FN, Nkrumah FK, et al. Characteristics of severe anemia and its association with malaria in young children of the Kassena- 
Nankana District of northern Ghana. Am J Trop Med Hyg. 2002; 67(4): 371-7.

49. Abba K, Deeks JJ, Olliaro P, Naing CM, Jackson SM, Takwoingi $Y$, et al. Rapid diagnostic tests for diagnosing uncomplicated $\mathrm{P}$. falciparum malaria in endemic countries. Cochrane Database Syst Rev. 2011; (7): CD008122.

50. Marx A, Pewsner D, Egger M, Nuesch R, Bucher $\mathrm{HC}$, Genton B, et al. Meta-analysis: accuracy of rapid tests for malaria in travelers returning from endemic areas. Ann Intern Med. 2005; 142(10): 836-46.

51. Ochola LB, Vounatsou P, Smith T, Mabaso ML, Newton CR. The reliability of diagnostic techniques in the diagnosis and management of malaria in the absence of a gold standard. Lancet Infect Dis. 2006; 6(9): 582-8.

52. Koita OA, Doumbo OK, Ouattara A, Tall LK, Konare A, Diakite $\mathrm{M}$, et al. False-negative rapid diagnostic tests for malaria and deletion of the histidine-rich repeat region of the hrp2 gene. Am J Trop Med Hyg. 2012; 86(2): 194-8.

53. WHO Malaria Policy Advisory Committee and Secretariat. Inaugural meeting of the malaria policy advisory committee to the WHO: conclusions and recommendations. Malar J. 2012; 11: 137.

54. Peeling RW, Mabey D. Point-of-care tests for diagnosing infections in the developing world. Clin Microbiol Infect. 2010; 16(8): 1062-9.

55. Bell D, Wongsrichanalai C, Barnwell JW. Ensuring quality and access for malaria diagnosis: how can it be achieved? Nat Rev Microbiol. 2006; 4(9 Suppl): S7-20. 56. Lon CT, Alcantara S, Luchavez J, Tsuyuoka R, Bell D. Positive control wells: a potential answer to remote-area quality assurance of malaria rapid diagnostic tests. Trans $R$ Soc Trop Med Hyg. 2005; 99(7): 493-8.

57. Rowe AK, de Savigny D, Lanata CF, Victora CG. How can we achieve and maintain high-quality performance of health workers in low-resource settings? Lancet. 2005; 366(9490): 1026-35.

58. Hamer DH, Ndhlovu M, Zurovac D, Fox M, Yeboah-Antwi K, Chanda $P$, et al. Improved Diagnostic Testing and Malaria Treatment Practices in Zambia. JAMA:. 2007; 297(20): 2227-31.

59. Bisoffi Z, Sirima BS, Angheben A, Lodesani C, Gobbi F, Tinto H, et al. Rapid malaria diagnostic tests vs. clinical management of malaria in rural Burkina Faso: safety and effect on clinical decisions. A randomized trial. Trop Med Int Health. 2009; 14(5): 491-8.

60. Reyburn H, Mbakilwa H, Mwangi R, Mwerinde O, Olomi R, Drakeley C, et al. Rapid diagnostic tests compared with malaria microscopy for guiding outpatient treatment of febrile illness in Tanzania: randomised trial. BMJ. 2007; 334(7590): 403.
61. Thiam S, Thior M, Faye B, Ndiop M, Diouf ML, Diouf MB, et al. Major reduction in anti-malarial drug consumption in Senegal after nation-wide introduction of malaria rapid diagnostic tests. PLoS One. 2011; 6(4): e18419.

62. Zurovac D, Sudoi RK, Akhwale WS, Ndiritu M, Hamer DH, Rowe AK, et al. The effect of mobile phone text-message reminders on Kenyan health workers' adherence to malaria treatment guidelines: a cluster randomised trial. Lancet. 2011; 378(9793): 795803.

63. Baiden F, Webster J, Owusu-Agyei S, Chandramohan D. Would rational use of antibiotics be compromised in the era of test-based management of malaria? Trop Med Int Health. 2011; 16(2): 142-4.

64. Bell D, Peeling RW. Evaluation of rapid diagnostic tests: malaria. Nat Rev Microbiol. 2006; 4(9 Suppl): S34-8.

65. Sayang C, Soula G, Tahar R, Basco LK, Gazin P, Moyou-Somo R, et al. Use of a histidine-rich protein 2based rapid diagnostic test for malaria by health personnel during routine consultation of febrile outpatients in a peripheral health facility in Yaounde, Cameroon. Am J Trop Med Hyg. 2009; 81(2): 343-7.

66. Msellem MI, Martensson A, Rotllant G, Bhattarai A, Stromberg J, Kahigwa E, et al. Influence of rapid malaria diagnostic tests on treatment and health outcome in fever patients, Zanzibar: a crossover validation study. PLoS Med. 2009; 6(4): e1000070.

67. Bastiaens GJ, Schaftenaar E, Ndaro A, Keuter M, Bousema T, Shekalaghe SA. Malaria diagnostic testing and treatment practices in three different Plasmodium falciparum transmission settings in Tanzania: before and after a government policy change. Malar J. 2011; 10: 76 .

68. Batwala V, Magnussen P, Nuwaha F. Antibiotic use among patients with febrile illness in a low malaria endemicity setting in Uganda. Malar J. 2011; 10: 377.

69. Nadjm B, Amos B, Mtove G, Ostermann J, Chonya $\mathrm{S}$, Wangai $\mathrm{H}$, et al. WHO guidelines for antimicrobial treatment in children admitted to hospital in an area of intense Plasmodium falciparum transmission: prospective study. BMJ. 2010; 340: c1350.

70. McMorrow ML, Masanja MI, Abdulla SM, Kahigwa E, Kachur SP. Challenges in routine implementation and quality control of rapid diagnostic tests for malaria--Rufiji District, Tanzania. Am J Trop Med Hyg. 2008; 79(3): 385-90.

71. Rowe AK, Onikpo F, Lama M, Osterholt DM, Deming MS. Impact of a malaria-control project in Benin that included the integrated management of childhood illness strategy. Am J Public Health. 2011; 101(12): 2333-41.

72. Vinnemeier CD, Schwarz NG, Sarpong N, Loag W, Acquah S, Nkrumah B, et al. Predictive Value of Fever and Palmar Pallor for P. falciparum Parasitaemia in 
Children from an Endemic Area. PLoS One. 2012; 7(5): e36678.

73. Chandler CI, Hall-Clifford R, Asaph T, Pascal M, Clarke $\mathrm{S}$, Mbonye $\mathrm{AK}$. Introducing malaria rapid diagnostic tests at registered drug shops in Uganda: limitations of diagnostic testing in the reality of diagnosis. Soc Sci Med. 2011; 72(6): 937-44.

74. Mukanga D, Tibenderana JK, Kiguli J, Pariyo GW, Waiswa P, Bajunirwe F, et al. Community acceptability of use of rapid diagnostic tests for malaria by community health workers in Uganda. Malar $J$. 2010; 9: 203.

75. Williams HA, Causer L, Metta E, Malila A, O'Reilly T, Abdulla S, et al. Dispensary level pilot implementation of rapid diagnostic tests: an evaluation of RDT acceptance and usage by providers and patients--Tanzania, 2005. Malar J. 2008; 7: 239.

76. Baiden F, Owusu-Agyei S, Okyere E, Tivura M, Adjei G, Chandramohan D, et al. Acceptability of Rapid Diagnostic Test-Based Management of Malaria among Caregivers of Under-Five Children in Rural Ghana. PLoS ONE 7(9): e45556 doi:101371/journalpone0045556. 2012.

77. Okiro EA, Hay SI, Gikandi PW, Sharif SK, Noor AM, Peshu N, et al. The decline in paediatric malaria admissions on the coast of Kenya. Malar J. 2007; 6: 151 .

78. Schellenberg D, Menendez C, Aponte J, Guinovart $\mathrm{C}$, Mshinda $\mathrm{H}$, Tanner $\mathrm{M}$, et al. The changing epidemiology of malaria in Ifakara Town, southern Tanzania. Trop Med Int Health. 2004; 9(1): 68-76.

79. Sharp BL, Kleinschmidt I, Streat E, Maharaj R, Barnes KI, Durrheim DN, et al. Seven years of regional malaria control collaboration--Mozambique, South Africa, and Swaziland. Am J Trop Med Hyg. 2007; 76(1): 42-7.

80. Jaenson TG, Gomes MJ, Barreto dos Santos RC, Petrarca V, Fortini D, Evora J, et al. Control of endophagic Anopheles mosquitoes and human malaria in Guinea Bissau, West Africa by permethrin-treated bed nets. Trans R Soc Trop Med Hyg. 1994; 88(6): 620-4.

81. Nyarango PM, Gebremeskel T, Mebrahtu G, Mufunda J, Abdulmumini U, Ogbamariam A, et al. A steep decline of malaria morbidity and mortality trends in Eritrea between 2000 and 2004: the effect of combination of control methods. Malar J. 2006; 5: 33.
82. Otten M, Aregawi M, Were W, Karema C, Medin $\mathrm{A}$, Bekele $\mathrm{W}$, et al. Initial evidence of reduction of malaria cases and deaths in Rwanda and Ethiopia due to rapid scale-up of malaria prevention and treatment. Malar J. 2009; 8: 14.

83. Sarrassat S, Senghor P, Le Hesran JY. Trends in malaria morbidity following the introduction of artesunate plus amodiaquine combination in M'lomp village dispensary, south-western Senegal. Malar J. 2008; 7: 215.

84. Russell TL, Govella NJ, Azizi S, Drakeley CJ, Kachur SP, Killeen GF. Increased proportions of outdoor feeding among residual malaria vector populations following increased use of insecticidetreated nets in rural Tanzania. Malar J. 2011; 10: 80.

85. Barnes KI, Chanda P, Ab Barnabas G. Impact of the large-scale deployment of artemether/lumefantrine on the malaria disease burden in Africa: case studies of South Africa, Zambia and Ethiopia. Malar J. 2009; 8 Suppl 1: S8.

86. Karema C, Aregawi MW, Rukundo A, Kabayiza A, Mulindahabi M, Fall IS, et al. Trends in malaria cases, hospital admissions and deaths following scale-up of anti-malarial interventions, 2000-2010, Rwanda. Malar J. 2012; 11(1): 236.

87. Nkrumah B, Agyekum A, Acquah SE, May J, Tannich E, Brattig N, et al. Comparison of the novel Partec rapid malaria test to the conventional Giemsa stain and the gold standard real-time PCR. J Clin Microbiol. 2010; 48(8): 2925-8.

88. Nkrumah B, Acquah SE, Ibrahim L, May J, Brattig N, Tannich E, et al. Comparative evaluation of two rapid field tests for malaria diagnosis: Partec Rapid Malaria Test(R) and Binax Now(R) Malaria Rapid Diagnostic Test. BMC Infect Dis. 2011; 11: 143.

89. Ayeh-Kumi PF, Akalifa BG, Obeng Nkrumah N, Asmah RH, Dayie NT. Performance of rapid DiaMed OptiMal-IT((R)) malaria test in an endemic Ghanaian setting. J Parasit Dis. 2011; 35(2): 129-33.

90. Baiden F, Webster J, Tivura M, Delimini R, Berko Y, Amenga-Etego S, et al. Accuracy of rapid tests for malaria and treatment outcomes for malaria and nonmalaria cases among under-five children in rural Ghana. PLoS One. 2012; 7(4): e34073. 